\title{
Plankton response following a spring upwelling event in the Ria de Arosa, Spain
}

\author{
R. B. Hanson ${ }^{1}$, M. T. Alvarez-Ossorio ${ }^{2}$, R. Cal ${ }^{2}$, M. J. Campos ${ }^{2}$, M. Roman ${ }^{3}$, \\ G. Santiago ${ }^{4}$, M. Varela ${ }^{2} \&$ J. A. Yoder ${ }^{1}$ \\ ${ }^{1}$ Skidaway Institute of Oceanography, P. O. Box 13687, Savannah, Georgia 31416, USA \\ ${ }^{2}$ I. E. O. Laboratorio de la Coruna, La Coruna, Spain \\ ${ }^{3}$ Horn Point Environmental Laboratories, University of Maryland, P. O. Box 775, Cambridge, Maryland 21613, USA \\ ${ }^{4}$ Instituto Español de Oceanografía (I. E. O.), Alcala 27, Madrid, Spain
}

\begin{abstract}
Phytoplankton and bacterioplankton growth dynamics, and biomass and ingestion rates of zooplankton and mussels hung from rafts in the Ria de Arosa, Spain, were studied after a spring upwelling event. Upwelling of North Atlantic Central Water was confirmed by salinity, temperature and nutrient properties of the bottorn waters in the Ria and the positive upwelling index calculated for the study period. On 11 March, 1983, primary production and chlorophyll a concentrations exceeded $30 \mathrm{mg} \mathrm{C} \mathrm{m} \mathrm{m}^{-3} \mathrm{~h}^{-1}$ and $10 \mathrm{mg} \mathrm{m}^{-3}$, respectively, in the surface waters. After the upwelling period primary production decreased to $<2 \mathrm{mg} \mathrm{C} \mathrm{m} \mathrm{m}^{-3} \mathrm{~h}^{-1}$. Our results show that bacterial growth dynamics were spatially (vertically) separated from phytoplankton growth dynamics following the upwelling event. The highest specific rate of bacterial production occurred below the depth of maximum photosynthesis and above the thermocline. The highest rates of bacterial production were $<10 \%$ of phytoplankton production. Zooplankton $(>333 \mu \mathrm{m})$ grazing experiments indicated an active selection of phytoplankton over bacteria and a sufficient grazing rate $\left(90\right.$ to $124 \% \mathrm{~d}^{-1}$ ) to crop the daily phytoplankton production. Thus, herbivorous zooplankton may at times be in direct competition for food with raft-mussel aquaculture in the Ria de Arosa.
\end{abstract}

\section{INTRODUCTION}

Upwelling of deep, nutrient-rich oceanic water onto continental shelves is a primary source of nitrogen and other plant elements supporting shelf food chains. In response to favorable winds, North Atlantic Central Water (NACW) upwells into the N. W. Spanish continental shelf, and then moves across the narrow $(20 \mathrm{~km}$ wide) shelf into the several fjord-like estuaries (Rias de Bajas) that line the Galician coast (Fig. 1). As a result of high plankton production resulting from the episodic influx of upwelled nutrients, an intensive mussel (Mytilus edulis L.) aquaculture has developed in the Rias de Bajas (Tenore et al. 1982, 1983).

Several physical, topographical and climatological conditions influence the upwelling off N. W. Spain and the intrusion of nutrient-rich waters into the rias (Fig. 1). Northeast winds that blow down the rias lower sea level at the mouth, which sets up a seaward pressure gradient forcing near-surface waters out of the rias, thereby allowing NACW to flow into the rias along the bottom (Fraga 1981, Blanton et al. 1984). Coastal bathymetry and the alignment of the rias also influence the magnitude and frequency of these intrusions in the

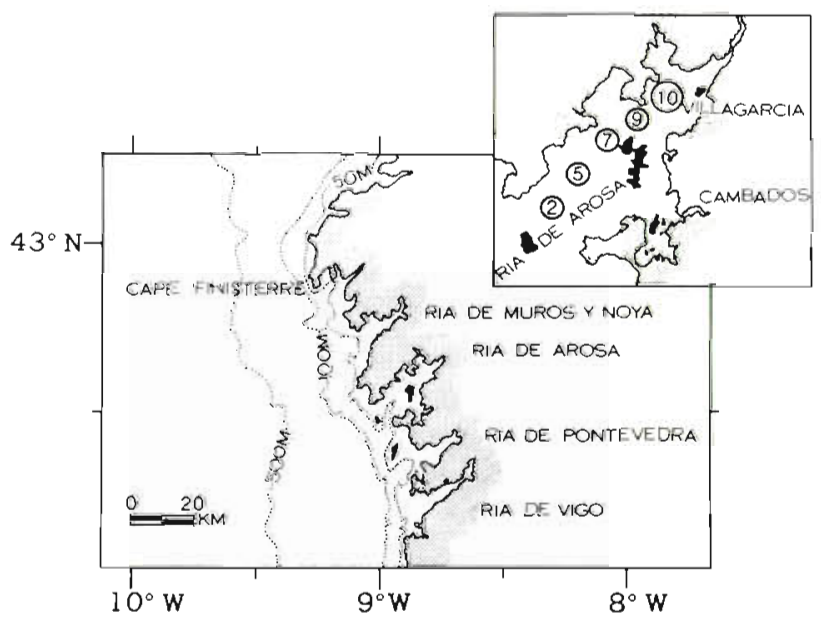

Fig. 1 Northwest Spanish coast and locations of stations occupied during the study of the Ria de Arosa 
bers used, have been shown to collect a representative sample of the zooplankton community as compared to net-collected samples (Houde \& Lovdal 1985). Zooplankton dry weights were converted to carbon biomass by assuming a carbon/dry weight ratio of $36 \%$ (Roman et al. 1985).

\section{RESULTS}

\section{Hydrography and phytoplankton production}

Previous investigators used sea surface pressure maps to calculate an upwelling index for the Ria de Arosa (Blanton et al. 1984). The index for March 1983 was positive indicating upwelling-favorable wind conditions during our study period (J. O. Blanton unpubl.). A hydrographic survey of the Ria de Arosa on 9 March showed that nutrient-rich NACW (salinity $>35.5 \mathrm{ppt}$ ) had intruded into the Ria enriching the upper $20 \mathrm{~m}$ (euphotic zone) of the water column with $\mathrm{NO}_{3}$ and other plant nutrients (Fig. 2). High concentrations of phytoplankton biomass (Chl a $>10 \mathrm{mg} \mathrm{m}^{-3}$ ) were located in the upper $20 \mathrm{~m}$ of the water column with a

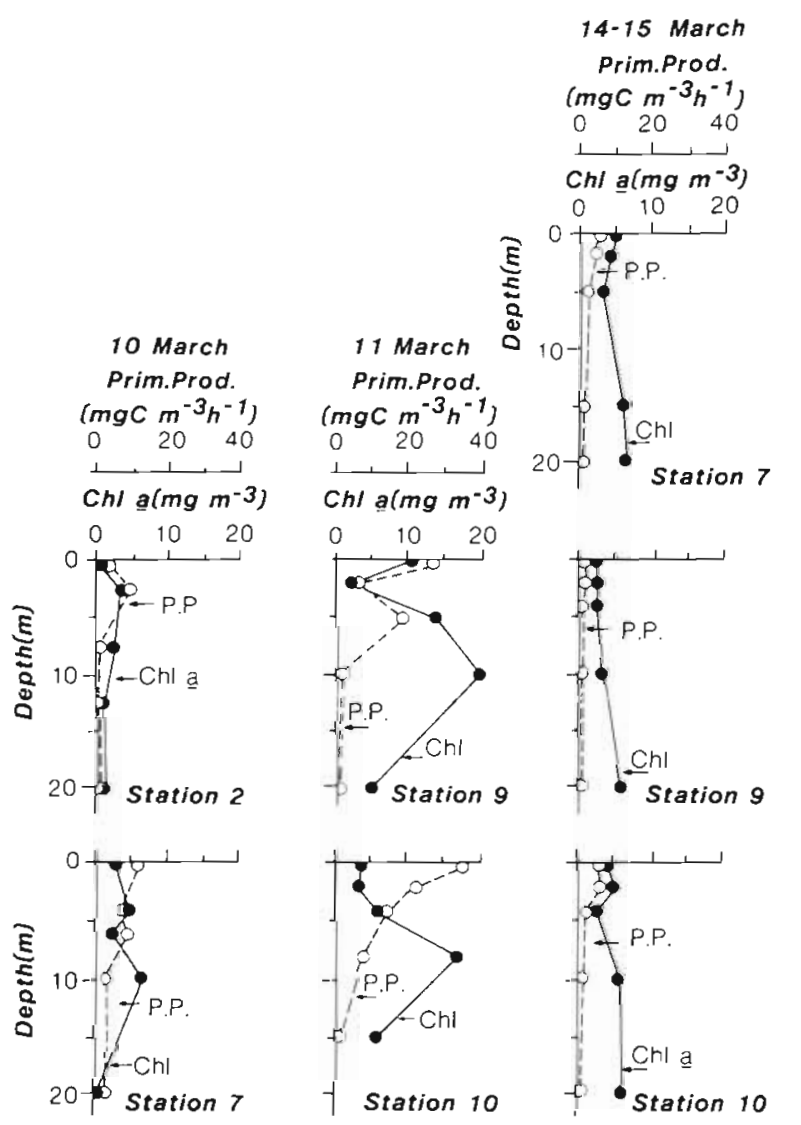

Fig. 4. Vertical distributions of primary production and chlorophyll $a$ on 10,11 and 14-15 Mar mixture of NACW and low-salinity waters from the inner Ria (Fig. 2). Following the initial survey on 9 March, plankton production and other responses were determined on 10,11, 14 and 15 March. As will be illustrated below, major biological and chemical changes occurred following the upwelling and intrusion of NACW into the Ria.

On 9 to 11 March $\mathrm{NO}_{3}$ exceeded $5 \mu \mathrm{M}$ in the upper $20 \mathrm{~m}$ throughout the $\mathrm{Ria} . \mathrm{NH}_{4}{ }^{+}$was generally less than $1.0 \mu \mathrm{M}$ in the euphotic zone (Fig. 2). In the inner Ria at Stns 9 and 10, a lens of low-salinity water of less than $5 \mathrm{~m}$ deep overlaid NACW (Fig. 3). Maximum Chl a concentrations occurred below the lens of low salinity water, reaching $20 \mathrm{mg} \mathrm{m}^{-3}$ in the intruded NACW (Fig. 4). Maximum Chl a concentrations in the middle and outer Ria (Stns 7 and 2, respectively) were lower than the inner Ria, reaching maximum concentrations of $<10 \mu \mathrm{mg} \mathrm{m} \mathrm{m}^{-3}$.

The middle and inner Ria were sampled again on 14 and $15 \mathrm{March}$, and conditions were very different from those described earlier. $\mathrm{NO}_{3}$ was near undetectable levels throughout the euphotic zone, and $\mathrm{NH}_{4}{ }^{+}$concentrations were generally above $1.0 \mu \mathrm{M}$ (Fig. 3). On 14-15 March, maximum Chl a concentrations at Stns 7 , 9 and 10 were $5 \mathrm{mg} \mathrm{m}^{-3}$ on 11 March (Fig. 4).

Primary production measurements are consistent with biomass measurements showing that the phytoplankton bloom was in a state of decline by 14-15 March (Fig. 4). The rate of primary production normalized by the concentration of $\mathrm{Chl}$ a (mg C mg Chl $\left.a^{-1} h^{-1}\right)$ is an indicator of phytoplankton growth potential (specific-rate of photosynthesis). On 10 and 11 March, the maximum specific-rate of photosynthesis was 5 to $10 \mathrm{mg} \mathrm{C} \mathrm{mg} \mathrm{Chl} a^{-1} \mathrm{~h}^{-1}$ (Fig. 5). By 14-15 March, the maximum rate declined to $<2 \mathrm{mg} \mathrm{C}$ mg Chl $a^{-1} h^{-1}$ indicating that phytoplankton were growing slower than 3 to $4 \mathrm{~d}$ earlier. On 10-11 March, photosynthesis saturated at an irradiance greater than $1000 \mu$ Ein $\mathrm{m}^{-2} \mathrm{~s}^{-1}$, whereas light saturation was less than $500 \mu$ Ein $\mathrm{m}^{-2} \mathrm{~s}^{-1}$ by 14-15 March (Fig. 5). To estimate phytoplankton-C biomass and growth rate,

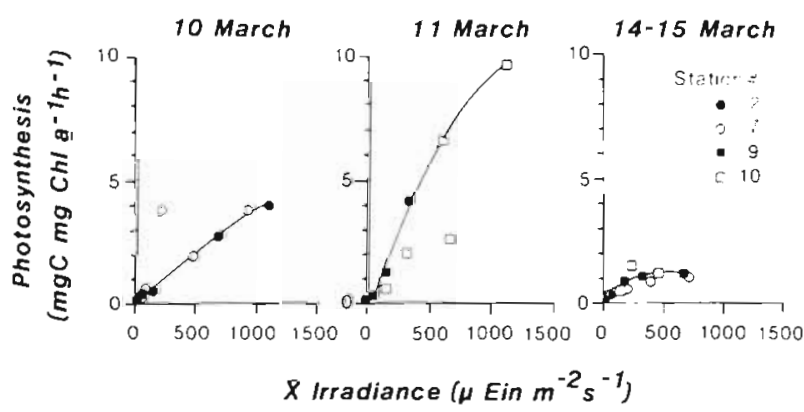

Fig. 5. Photosynthesis versus irradiance curves on 10,11 and 14-15 Mar 
Table 1. Phytoplankton production, biomass and growth rates

\begin{tabular}{|c|c|c|c|c|c|c|c|c|c|c|c|}
\hline \multicolumn{4}{|c|}{$10 \mathrm{Mar}$} & \multicolumn{4}{|c|}{$11 \mathrm{Mar}$} & \multicolumn{4}{|c|}{ 14-15 Mar } \\
\hline Stn & Depth & $\bar{X}$ & Range & Stn & Depth & $\bar{X}$ & Range & Stn & Depth & $\bar{x}$ & Range \\
\hline \multicolumn{12}{|c|}{ Production (mg C $\mathrm{m}^{-3} \mathbf{h}^{-1}$ ) } \\
\hline 2 & $0-40$ & 2.95 & $0.05-9.60$ & 9 & $0-20$ & 12.10 & $0.18-26.20$ & 7 & $0-20$ & 2.42 & $0.36-5.91$ \\
\hline \multirow[t]{2}{*}{7} & $0-20$ & 6.22 & $0.11-10.70$ & 10 & $0-15$ & 15.39 & $0.33-34.66$ & 9 & $0-20$ & 1.60 & $0.17-3.07$ \\
\hline & & & & & & & & 10 & $0-20$ & 2.44 & $0.10-5.44$ \\
\hline \multicolumn{12}{|c|}{ Biomass (mg C m${ }^{3}$ ) } \\
\hline 2 & $0-40$ & 113 & $12-122$ & 9 & $0-20$ & 358 & $70-700$ & 7 & $0-20$ & 170 & $112-224$ \\
\hline \multirow[t]{2}{*}{7} & $0-20$ & 118 & $32-158$ & 10 & $0-15$ & 249 & $112-602$ & 9 & $0-20$ & 110 & $70-210$ \\
\hline & & & & & & & & 10 & $0-20$ & 165 & $84-210$ \\
\hline \multicolumn{12}{|c|}{ Growth rates $\left(\mathbf{d}^{-1}\right)$} \\
\hline 2 & $0-40$ & 0.62 & $0.10-1.89$ & 9 & $0-20$ & 0.81 & $0.60-0.90$ & 7 & $0-20$ & 0.34 & $0.078-0.63$ \\
\hline \multirow[t]{2}{*}{7} & $0-20$ & 1.26 & $0.08-1.61$ & 10 & $0-15$ & 1.31 & $0.071-1.39$ & 9 & $0-20$ & 0.34 & $0.058-0.85$ \\
\hline & & & & & & & & 10 & $0-20$ & 0.35 & $0.029-0.62$ \\
\hline
\end{tabular}

we assumed a $24 \mathrm{~h}$ growth period and a C:Chl a ratio of 45:1 (Malone et al. 1983). These estimates show that the highest production, biomass and growth rate (Production:Biomass ratio) occurred on 11 March (Table 1). During the phytoplankton decline, the mean growth rate was $0.72 \pm 0.42(\mathrm{SD}) \mathrm{d}^{-1}$, range $<0.1$ to $1.89 \mathrm{~d}^{-1}$.

Phytoplankton species were enumerated at Stns 7, 9 and 10 on 14 and 15 March. Diatoms were dominant and exceeded $10^{6}$ cells $\mathrm{l}^{-1}$. Small $(<5 \mu \mathrm{m})$ flagellates and dinoflagellates were also present at concentrations generally $<10^{5}$ cells $l^{-1}$. The dominant diatom species were Chaetoceros holsaticus which accounted for more than $90 \%$ of the total diatom cells.

\section{Bacterioplankton production and biomass}

Vertical distributions and daily variations of TdR incorporation $\left(\right.$ mean $=91 \pm 47.6(\mathrm{SD}) \mathrm{pmol} \mathrm{l}^{-1} \mathrm{~d}^{-1}$, range 38 to $191 \mathrm{pmol} \mathrm{l}^{-1} \mathrm{~d}^{-1}$ ) in the Ria de Arosa between 9 and 15 March are shown in Fig. 6. Bacterial abundance was also highly variable over depth and

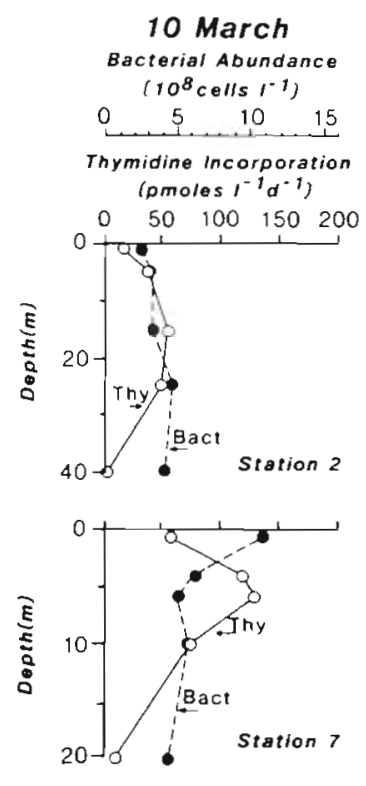

10 March

$\left(10^{8} c e l / s(-1)\right.$
$(5$ )

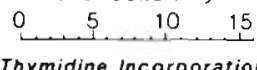

(pmoles $1^{-1} d^{-1}$ )
11 March Bacterial Abundance $\left(10^{8} \mathrm{cel} / \mathrm{s}(-1)\right.$ ㄴ... 5... $10 \quad 15$ Thymidine Incorporation (pmoles $1^{-1} d^{-1}$ )
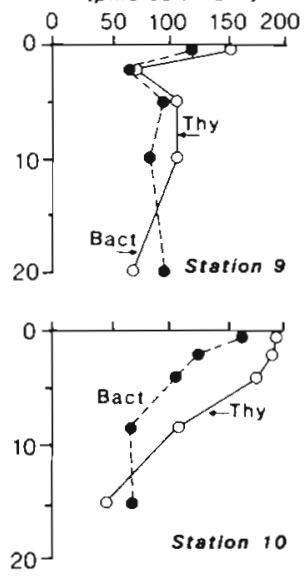

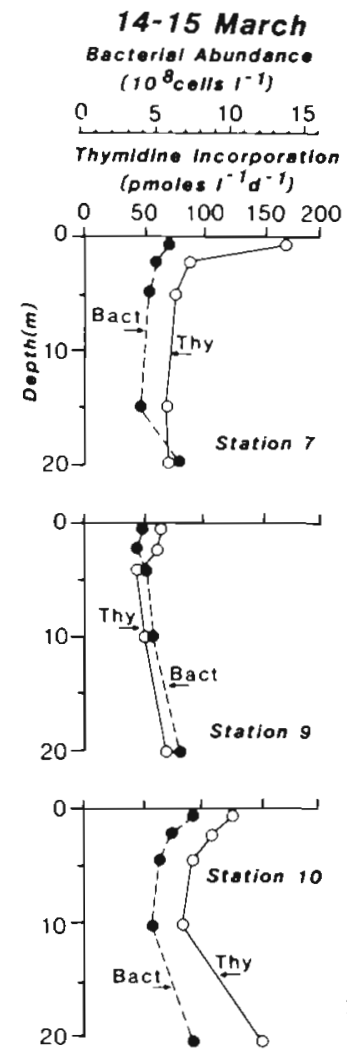

Fig. 6. Vertical distribution of thymidine incorporation and bacterial abundance on 10,11 and $14-15 \mathrm{Mar}$ 
Table 2. Bacterial production, biomass, and growth rates; $N=5$ depths

\begin{tabular}{|c|c|c|c|c|c|c|c|c|c|c|c|}
\hline \multicolumn{4}{|c|}{$10 \mathrm{Mar}$} & \multicolumn{4}{|c|}{$11 \mathrm{Mar}$} & \multicolumn{4}{|c|}{ 14-15 Mar } \\
\hline Stn & Depth & $\overline{\mathrm{X}}$ & Range & Stn & Depth & $\bar{X}$ & Range & Stn & Depth & $\bar{x}$ & Range \\
\hline \multicolumn{12}{|c|}{ Production ( $\mathrm{mg} \mathrm{C} \mathrm{m}^{-3} \mathrm{~d}^{-1}$ ) } \\
\hline 2 & $0-40$ & 0.76 & $0-1.07$ & 9 & $0-20$ & 2.00 & $1.37-3.02$ & 7 & $0-20$ & 1.87 & $1.33-3.34$ \\
\hline \multirow[t]{2}{*}{7} & $0-20$ & 2.04 & $1.20-2.66$ & 10 & $0-15$ & 2.86 & $0.95-3.82$ & 9 & $0-20$ & 1.13 & $0.85-1.35$ \\
\hline & & & & & & & & 10 & $0-20$ & 2.27 & $1.71-3.08$ \\
\hline \multicolumn{12}{|c|}{ Biomass ( $\mathrm{mg} \mathrm{C} \mathrm{m}^{3}$ ) } \\
\hline 2 & $0-40$ & 1.78 & $1.25-2.35$ & 9 & $0-20$ & 3.67 & $2.85-4.65$ & 7 & $0-20$ & 2.37 & $1.85-3.05$ \\
\hline \multirow[t]{2}{*}{7} & $0-20$ & 3.33 & $2.35-5.50$ & 10 & $0-15$ & 4.22 & $2.65-6.50$ & 9 & $0-20$ & 2.15 & $1.65-3.10$ \\
\hline & & & & & & & & 10 & $0-20$ & 3.08 & $2.25-3.80$ \\
\hline \multicolumn{12}{|c|}{ Growth rates $\left(d^{-1}\right)$} \\
\hline 2 & $0-40$ & 0.30 & $0-0.65$ & 9 & $0-20$ & 0.56 & $0.35-0.67$ & 7 & $0-20$ & 0.78 & $0.46-1.28$ \\
\hline \multirow[t]{2}{*}{7} & $0-20$ & 0.56 & $0.22-1.02$ & 10 & $0-15$ & 0.67 & $0.32-0.85$ & 9 & $0-20$ & 0.55 & $0.43-0.71$ \\
\hline & & & & & & & & 10 & $0-20$ & 0.74 & $0.66-0.81$ \\
\hline
\end{tabular}

time (mean $5.89 \pm 2.34(\mathrm{SD}) \times 10^{8}$ cells $\mathrm{l}^{-1}$, range 2.5 to $12 \times 10^{8}$ cells $\left.\mathrm{l}^{-1}\right)$, but correlated $\left(\mathrm{r}^{2}=0.673\right.$, $\mathrm{P}<0.001$ ) with $\mathrm{TdR}$ incorporation (thymidine incorporation $=18.3 \pm 15.4(\mathrm{SE})+12.6 \pm 2.4$ bacteria abundance; $F$ statistic $=26.5, \mathrm{df}=32$ ). The rate of $\mathrm{TdR}$ incorporation per cell averaged $1.4 \pm 0.63$ (SD) $\times$ $10^{-19}$ moles cell $\mathrm{d}^{-1}$, range 0.25 to $3.2 \times 10^{-19}$ moles cell ${ }^{-1} \mathrm{~d}^{-1}$. TdR incorporation per cell (specific TdR incorporation per cell (specific $\mathrm{TdR}$ incorporation rate) is an index of specific growth rates (Ducklow \& Hill 1985). Specific incorporation rates were not correlated with bacterial abundance, suggesting that bacterial production was bacterial density-independent. Assuming $5 \times 10^{-15} \mathrm{~g} \mathrm{C} \mathrm{cell}^{-1}$ (Watson et al. 1977) and a conservative conversion factor of $4 \times 10^{18}$ cells produced per mole of TdR incorporated (see Fuhrman \& Azam 1982, Ducklow \& Hill 1985), we calculate a mean growth rate ( $P: B$ ratio) of $0.60 \pm 0.26(\mathrm{SD}) \mathrm{d}^{-1}$, range $<0.1$ to $1.28 \mathrm{~d}^{-1}$ (Table 2).

Thymidine uptake was also determined independ-

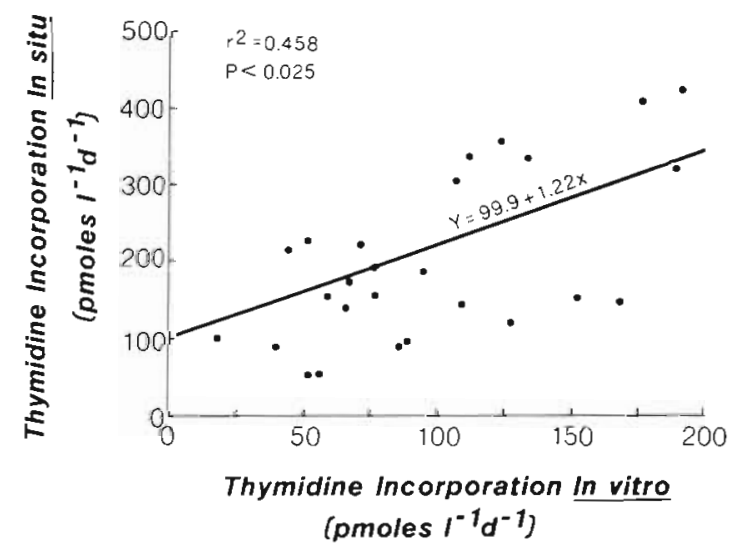

Fig. 7. Relation between the rates of thymidine incorporation measured in situ during the zooplankton grazing experiment (Fig. 13) and in vitro in water-cooled incubators (Fig. 6) ently from zooplankton grazing experiments. The rates of TdR uptake measured in situ averaged $216 \pm 126$

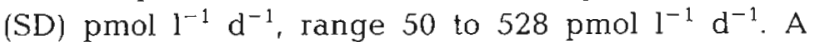
strong linear correlation $\left(\mathrm{r}^{2}=0.458, \mathrm{P}<0.02\right)$ was found between the 2 techniques (Fig. 7).

\section{Bacterial-phytoplankton linkage}

Bacterioplankton and phytoplankton were compared after the upwelling event in the Ria de Arosa. Linear regression analysis indicated a strong correlation $\left(\mathrm{r}^{2}=\right.$ $0.652, \mathrm{P}<0.001$ ) between thymidine incorporation and photosynthesis (Fig. 8). However, thymidine incorporation was weakly correlated $\left(\mathrm{r}^{2}=0.334, \mathrm{P}<0.1\right)$ with phytoplankton biomass (Fig. 9A). Because of the high biomass $(\mathrm{Chl}$ a) on 11 March the data were analysed to assess daily variation on bacterioplankton productionphytoplankton biomass (Fig. 9B). Bacterioplankton production was strongly correlated $\left(\mathrm{r}^{2}=0.703\right.$, $P<0.05)$ with phytoplankton biomass on $10 \mathrm{March}$ and weakly correlated $\left(r^{2}=0.441, P<0.1\right)$ on $14-15$ March. No correlation was found on 11 March. From analysis

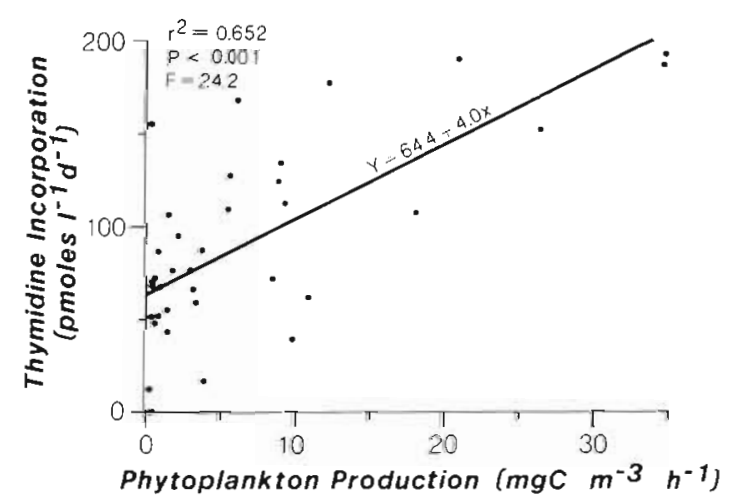

Fig. 8. Relation between rates of thymidine incorporation (Fig. 6) and phytoplankton production (Fig. 4) 

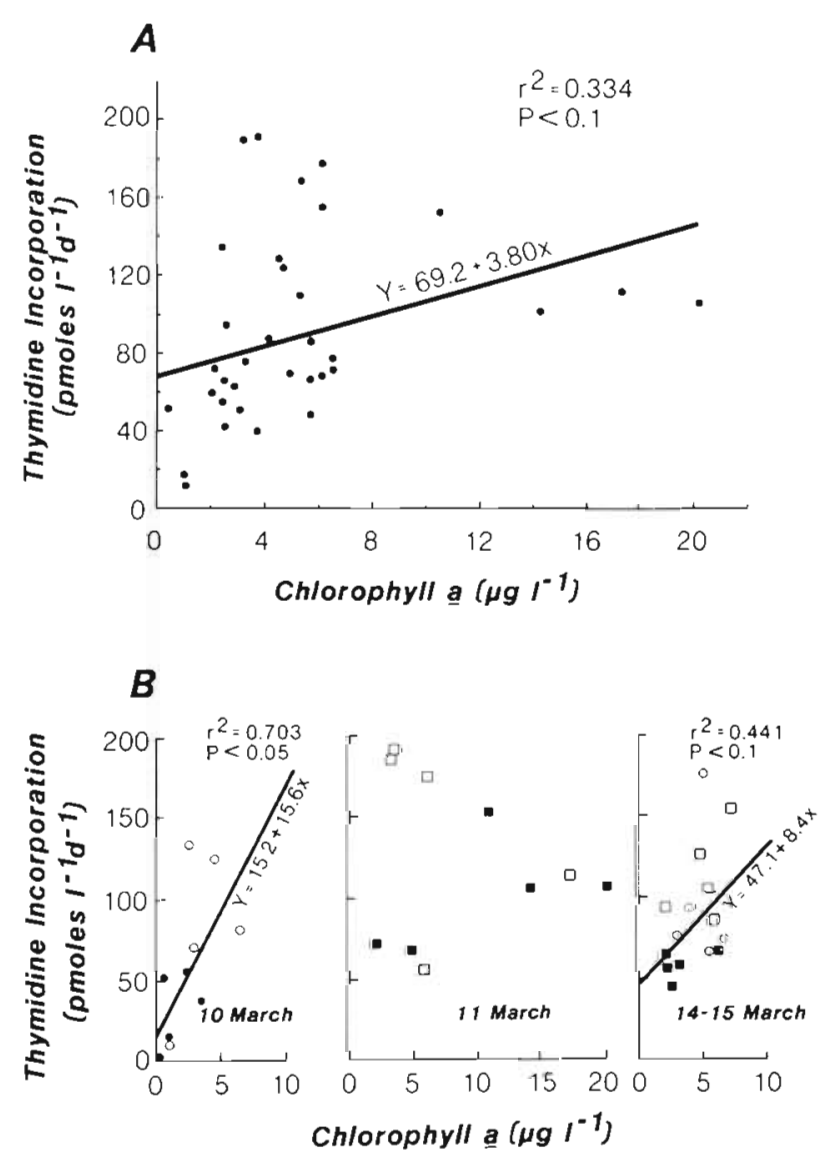

Fig. 9. Relation between rates of thymidine incorporation and chlorophyll a. (A) Data pooled for all stations, depths and times; (B) data from (A) except data pooled for each day (see Fig. 5). Symbols as in Fig. 10

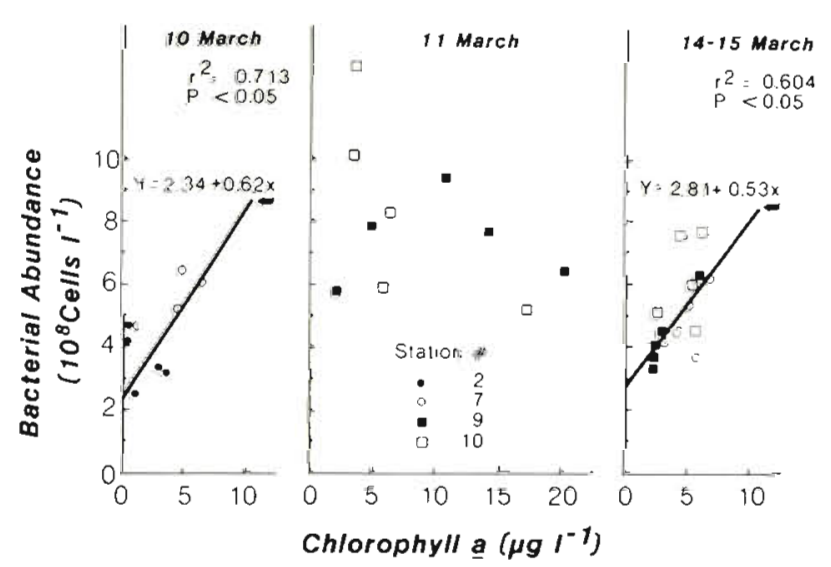

Fig. 10. Relation between bacterial abundance and phytoplankton chlorophyll a for each day (see Fig. 6)

of covariance (AOCOV), the positive slopes for 10 and 14-15 March were not significantly different (F statistics $=0.479 ; \mathrm{df}=23$ ). A linear regression analysis of the pooled data showed a highly significant correlation $\left(\mathrm{r}^{2}=0.647, \mathrm{P}<0.001\right)$, suggesting that bacterioplankton production was coupled (thymidine incorporation $=23.1 \pm 14.4[\mathrm{SE}]+14.5 \pm 3.6 \mathrm{Chl}$ a) to phytoplankton biomass on 10 March and 14-15 March.

In general, bacterial abundance and phytoplankton biomass were not correlated $\left(\mathrm{r}^{2}=0.223, \mathrm{P}>0.1\right)$ in the Ria de Arosa. However, like bacterial production and phytoplankton biomass, significant correlations were found between bacterioplankton abundance and phytoplankton biomass on $10 \mathrm{March}\left(\mathrm{r}^{2}=0.713, \mathrm{P}<0.05\right)$ and on 14-15 March $\left(r^{2}=0.604, P<0.05\right)$ (Fig. 10).

Table 3. Zooplankton biomass, weight-specific grazing rate, and water column clearance rate; $\mathrm{N}=4$ depths

\begin{tabular}{|c|c|c|c|c|c|c|c|c|c|c|c|c|c|c|}
\hline Stn & Depth & & $\frac{M^{a r}}{X}$ & Range & Stn & Depth & & $\frac{\operatorname{Mar}}{x}$ & Range & Stn & Depth & $14-$ & $5 \frac{\operatorname{Mar}}{\mathrm{X}}$ & Range \\
\hline \multicolumn{15}{|c|}{ Biomass (mg C m ${ }^{-3}$ ) } \\
\hline 2 & $0-25$ & & 56.5 & $47.0-70.6$ & 9 & $0-10$ & & 66.8 & $49.4-85.0$ & 7 & $0-15$ & & 56.6 & $47.2-65.8$ \\
\hline \multirow[t]{2}{*}{7} & $0-10$ & & 75.0 & $37.8-107.8$ & 10 & $0-8$ & & 77.2 & $42.0-133.2$ & 9 & $0-10$ & & 82.0 & $55.4-93.4$ \\
\hline & & & & & & & & & & 10 & $0-10$ & & 196.6 & $129.4-294.4$ \\
\hline \multicolumn{15}{|c|}{ Weight-specific grazing rate (l filtered $\mathrm{mg} \mathrm{C}^{-1} \mathrm{~d}^{-1}$ ) } \\
\hline \multirow[t]{2}{*}{2} & $0-25$ & A & 3.7 & $0.7-5.4$ & 9 & $0-10$ & A & 17.8 & $4.5-39.9$ & 7 & $0-15$ & A & 0.7 & $0.1-2.0$ \\
\hline & & $\mathrm{H}$ & 1.5 & $0.2-2.5$ & & & $\mathrm{H}$ & 3.8 & $1.3-5.4$ & & & $\mathrm{H}$ & 0.3 & $0.1-0.6$ \\
\hline \multirow[t]{4}{*}{7} & $0-10$ & A & 3.3 & $1.0-8.3$ & 10 & $0-8$ & A & 14.5 & $1.8-24.6$ & 9 & $0-10$ & A & 9.3 & $4.0-17.0$ \\
\hline & & $\mathrm{H}$ & 1.2 & $0.1-2.4$ & & & $\mathrm{H}$ & 2.4 & $0.2-5.3$ & & & $\mathrm{H}$ & 4.2 & $1.7-6.3$ \\
\hline & & & & & & & & & & 10 & $0-10$ & A & 3.6 & $1.1-6.9$ \\
\hline & & & & & & & & & & & & $\mathrm{H}$ & 3.0 & $0.4-5.8$ \\
\hline \multicolumn{15}{|c|}{ Water column clearance rate $\left(\% \mathrm{~m}^{-3}\right.$ filtered $\left.\mathbf{d}^{-1}\right)$} \\
\hline \multirow[t]{2}{*}{2} & $0-25$ & A & 19.3 & $4.9-29.6$ & 9 & $0-10$ & A & 124.2 & $22.2-305.6$ & 7 & $0-15$ & A & 4.3 & $0.5-13.2$ \\
\hline & & $\mathrm{H}$ & 8.0 & $1.4-13.7$ & & & $\mathrm{H}$ & 25.4 & $7.3-39.8$ & & & $\mathrm{H}$ & 1.9 & $0.5-3.9$ \\
\hline \multirow[t]{4}{*}{7} & $0-10$ & A & 28.7 & $6.8-57.0$ & 10 & $0-8$ & A & 89.3 & $24.0-189.6$ & 9 & $0-10$ & A & 81.4 & $22.2-158.8$ \\
\hline & & $\mathrm{H}$ & 13.8 & $0.4-25.9$ & & & $\mathrm{H}$ & 13.1 & $2.7-22.3$ & & & $\mathrm{H}$ & 34.3 & $15.8-54.3$ \\
\hline & & & & & & & & & & 10 & $0-10$ & A & 62.0 & $20.0-124.5$ \\
\hline & & & & & & & & & & & & $\mathrm{H}$ & 48.8 & $11.8-104.6$ \\
\hline
\end{tabular}

A: grazing rate on autotrophic particles $(>3.0 \mu \mathrm{m}) ; \mathrm{H}$ : grazing rate on heterotrophic particles $(>3.0 \mu \mathrm{m})$ 


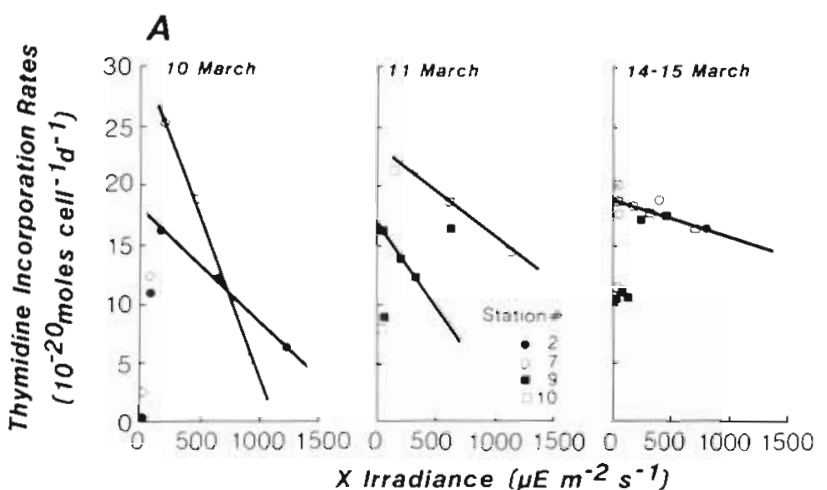

$B$

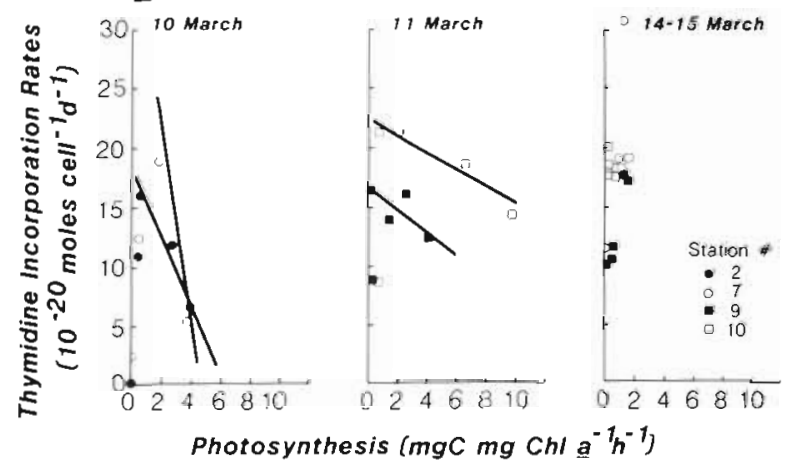

Fig. 11. Relation between thymidine incorporation rates and irradiance (A) and photosynthesis (B) for each day. Lines were hand-drawn through those points above the thermocline

From AOCOV, the positive slopes (10 March and 14-15 March) were not significantly different (F statistics $=0.975, \mathrm{df}=23$ ), and the pooled data showed a highly significant correlation $\left(\mathrm{r}^{2}=0.601, \mathrm{P}<0.001\right)$ : linear regression equation, (bacterial abundance $=3.3$ $\pm 0.5[\mathrm{SE}]+0.42 \pm 0.12 \mathrm{Chl}$ a) .

The specific rate of photosynthesis correlated with the irradiance level in the water column and the highest specific rates were found on 11 March (see Fig. 5). Plotting specific incorporation rates (TdR incorporated cell ${ }^{-1} \mathrm{~d}^{-1}$ ) against irradiance (Fig. 11A), we find an inverse relation in the euphotic zone above the thermocline (Fig. 3). The highest specific-rates of incorporation were at the 1 to $10 \%$ light level, i.e. the lowest specific rates were in surface and near-bottom waters. Likewise, plotting bacterial specific incorporation rates against phytoplankton specific-rate of photosynthesis (Fig. 11B), we find that when specific rate of photosynthesis are greater than $2 \mathrm{mg} \mathrm{C} \mathrm{mg} \mathrm{Chl} a^{-1} \mathrm{~h}^{-1}$ the specific rates of thymidine incorporation were inversely related to specific rates of photosynthesis $(10$ and 11 March). On 14-15 March when the phytoplankton growth was $<2 \mathrm{mg} \mathrm{C} \mathrm{mg} \mathrm{Chl} a^{-1} \mathrm{~h}^{-1}$, specific rates of incorporation in the euphotic zone clustered between 18 and $20 \times 10^{-21}$ moles cell ${ }^{-1} \mathrm{~d}^{-1}$. Below the $1 \%$ light level, specific rates of incorporation decreased by $50 \%$.

\section{Zooplankton biomass and grazing rates}

Zooplankton biomass showed no clear pattern of increase or decrease with depth or time in the Ria de Arosa (Table 3). Generally, zooplankton biomass aver-

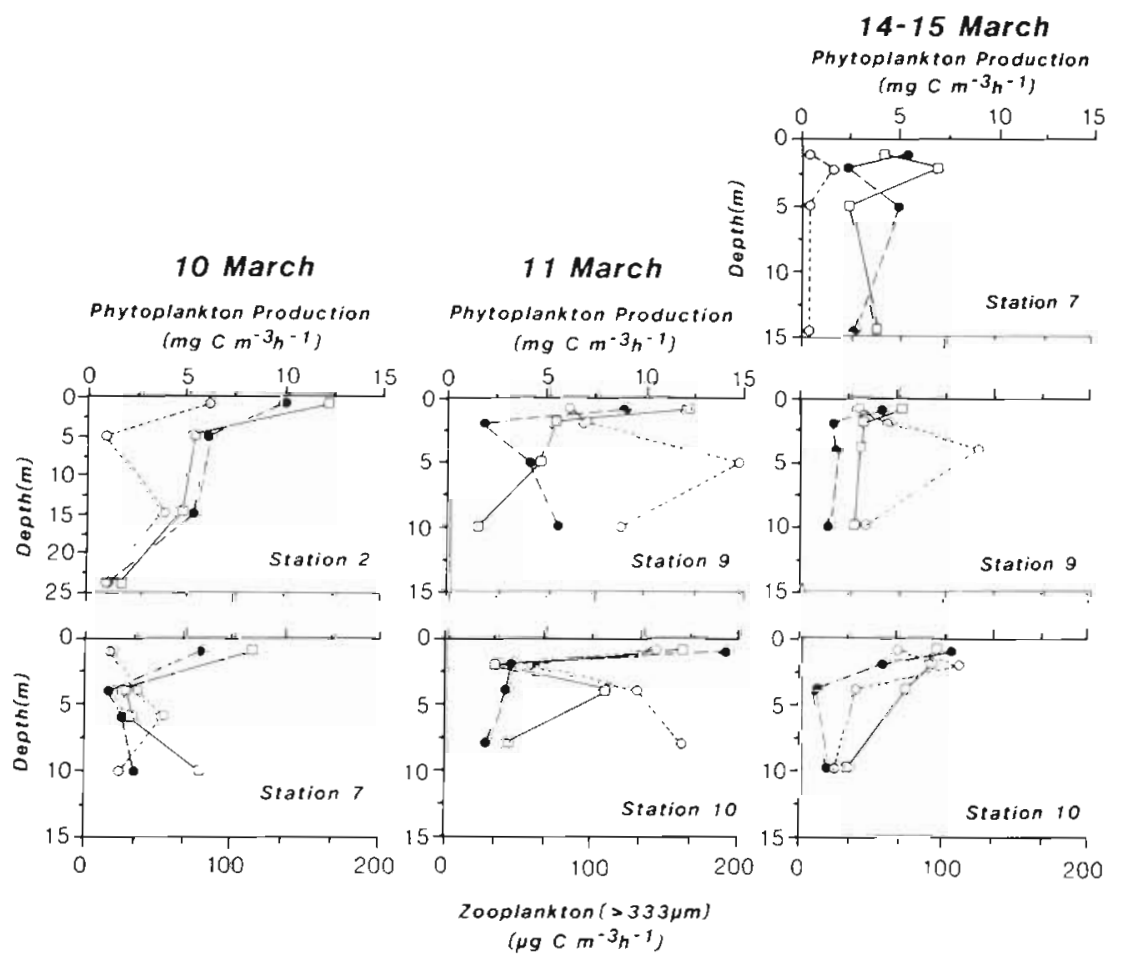

Fig. 12. Vertical distributions of in situ measurements of primary production ( $\mathrm{mg} \mathrm{C} \mathrm{m} \mathrm{m}^{-3} \mathrm{~h}^{-1}$ ) by $>0.2 \mu \mathrm{m}$ (口) and $>3.0 \mu \mathrm{m}(\bullet)$ size fractions, and zooplankton $(>333 \mu \mathrm{m})$ grazing $\left(\mu \mathrm{g} \mathrm{C} \mathrm{m}^{-3} \mathrm{~h}^{-1}\right.$, 


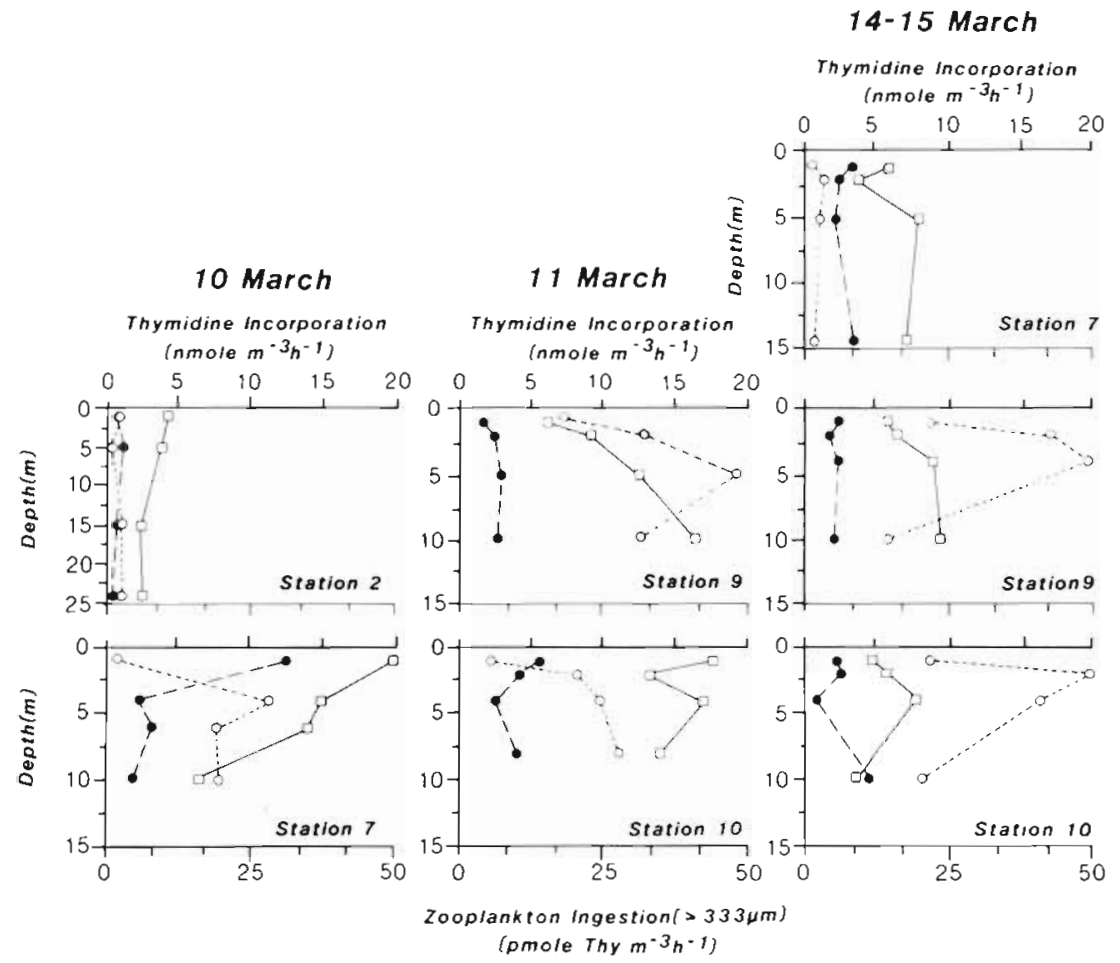

Fig. 13. Vertical distribution of in situ measurements of thymidine uptake (nmole thymidine $\mathrm{m}^{-3} \mathrm{~h}^{-1}$ ) by $>0.2 \mu \mathrm{m}$ $(\square)$ and $>3.0 \mu \mathrm{m}(\bullet)$ size fraction, and zooplankton $(>333 \mu \mathrm{m}$ ) grazing (pmoles thymidine $\left.\mathrm{m}^{-3} \mathrm{~h}^{-1},[0]\right)$ aged between 10 and $50 \mathrm{mg} \mathrm{C} \mathrm{m} \mathrm{m}^{-3}$. One exception was found on 14 March at Stn 10 where zooplankton standing crops biomass averaged $197 \mathrm{mg} \mathrm{C} \mathrm{m}^{-3}$.

In situ phytoplankton production rates were dominated by cells $>3.0 \mu \mathrm{m}$ (Fig. 12). However, at Stn 10 on March 14 the $<3$ um fraction below $5 \mathrm{~m}$ contributed to over $50 \%$ of the carbon fixation. In general, the uptake of autotrophic particles by zooplankton followed the same pattern with depth as phytoplankton production (Fig. 1). Average weight-specific zooplankton grazing rates of autotrophic particles of $>3.0 \mu \mathrm{m}$ were highest on 11 March at Stns 9 and 10 (18 and 14 l filtered $\mathrm{mg}$ $\mathrm{C}^{-1} \mathrm{~d}^{-1}$, respectively) during highest phytoplankton production (Table 3, see Fig. 5). Water column clearance rates of autotrophic particles (weight-specific grazing rates $\times$ biomass) ranged from 4 to $124 \% \mathrm{~d}^{-1}$ (Table 3). The highest grazing rates (89 to $124 \% \mathrm{~d}^{-1}$ ) were recorded on March 11, suggesting that zooplankton grazing was sufficient to crop the observed daily phytoplankton production.

Zooplankton grazing rates on heterotrophic particles were not correlated with the depth distribution of $T d R$ uptake by either $>3.0$ or $>0.2 \mu \mathrm{m}$ particulate fractions (Fig. 13). TdR uptake by $>3.0 \mu \mathrm{m}$ particles ranged from 20 to $40 \%$ of the total uptake $(>0.2 \mu \mathrm{m})$ in the Ria de Arosa. Zooplankton weight-specific grazing rates on heterotrophic particles were always less than those values for autotrophic particles (Table 3). Average water column clearance rates at the various stations varied from 2 to $49 \% \mathrm{~d}^{-1}$ (Table 3 ). The highest water column clearance rates ( 34 and $49 \% \mathrm{~d}^{-1}$ ) on heterotrophic particulate matter were measured on 14 March at Stns 9 and 10.

\section{DISCUSSION}

\section{Phytoplankton productivity}

Temporal changes in primary production and chlorophyll a concentration during our study occurred as a result of an influx of nutrient-rich NACW into the Ria de Arosa. This upwelling event caused an intense but short-lived diatom bloom. A previous study discussed the importance of these blooms to the productivity of the Ria during spring, and our results support these earlier conclusions (Campos-Loriz \& Gonzalez 1976). During this study, the highest specific rates of photosynthesis were 5 to $10 \mathrm{mg} \mathrm{Cmg} \mathrm{Chl} a^{-1} \mathrm{~h}^{-1}$, which are relatively high and comparable to spring bloom conditions in estuaries along the northeastern United States coast (e.g. Durbin et al. 1975, Malone \& Neale 1981), where springtime water temperatures and solar isolation are similar to those of the Ria de Arosa in March. These high specific rates indicate that phytoplankton were growing relatively fast (about 1 division $\mathrm{d}^{-1}$ ) and were in good physiological condition. Once $\mathrm{NO}_{3}^{-}$was depleted, specific rates declined to $<2 \mathrm{mg} \mathrm{C} \mathrm{mg}$ Chl $a^{-1} h^{-1}$. Such low numbers are characteristic of nutrient-stressed phytoplankton populations (e.g. Harrison et al. 1981). These results suggest that phyto- 
plankton populations in the Ria de Arosa frequently shift between relatively fast and slow growth periods with fast periods following an influx of upwelled NACW.

\section{Bacterioplankton production}

Our estimates of bacterioplankton incorporation of thymidine into DNA $\left(<10\right.$ to $200 \mathrm{pmol}$ as $\left.1^{-1} \mathrm{~d}^{-1}\right)$ fall within the low range of reported values (1 to 10000 pmoles $\mathrm{l}^{-1} \mathrm{~d}^{-1}$ ) (Table 4). The reason(s) for the low rates of $T d R$ incorporation by bacteria in the Ria de Arosa is not clear; especially when we compare our values of specific TdR incorporation rates and turnover times with other systems (Table 4). One explanation for the low TdR incorporation and high specific incorporation rates is that a higher percentage of the bacterial population, albeit also low for a temperate estuary (Table 4), is active. This can occur if the removal rate of bacteria by flagellates and ciliates is high, thereby maintaining the bacterial population in an active growth state but at a low density per unit volume.

Bacterial production in Ria de Arosa was calculated by assuming $4 \times 10^{18}$ cells produced per mole of TdR incorporated (Ducklow \& Hill 1985) and $5 \times 10^{-15} \mathrm{~g} \mathrm{C}$ per bacterial cell (Watson et al. 1977). Both factors seem reasonable considering the variation and range of values reported in the literature. Using these factors the resultant conversion of $T d R$ incorporation should be within a factor of 2 or 3 of the in situ bacterial production (Ducklow \& Hill 1985). Estimates of bacterial production for the Ria de Arosa between 10 and 15 March 1983 averaged $1.82 \pm 0.94 \mathrm{mg} \mathrm{C} \mathrm{m}^{-3} \mathrm{~d}^{-1}$ (range 0.76 to $3.82 \mathrm{mg} \mathrm{C} \mathrm{m} \mathrm{C}^{-1}$ ). Production : biomass ratio, an estimate of bacterial generation rates, ranged between 0.5 and $1 \mathrm{~d}^{-1}$ (Table 2). A comparison of bacterial production and phytoplankton production suggests that on 10 and 11 March bacterial production was 2 to $4 \%$ of phytoplankton production assuming an
8 h photoperiod per day. By the end of the study period (March 14-15), the percentage increased to $10 \%$. Comparisons of bacterial and phytoplankton production made elsewhere range between 5 and $25 \%$ (Fuhrman \& Azam 1982, Larson \& Hagström 1982, Newell \& Fallon 1982, Joint \& Pomroy 1983).

\section{Bacterial and phytoplankton growth dynamics}

Primary production (DOC and POC) is a major source of readily available metabolites for oceanic bacteria (van Es \& Meyer-Reil 1982, Azam et al. 1983, Williams 1984). Our results show that bacterial production (TdR) was strongly correlated $(\mathrm{P}<0.001)$ with phytoplankton photosynthesis in the Ria de Arosa, suggesting a strong relation between bacterioplankton growth and possibly photosynthate release from phytoplankton. A much weaker correlation was seen between bacterial $T d R$ incorporation (as well as bacterial abundance) and Chl a concentrations in the Ria, which was attributed to the increased phytoplankton biomass at 5 to $10 \mathrm{~m}$ on 11 March. Excluding this data, statistically significant correlations were found between $T d R$ incorporation (as well as bacterial abundance) and Chl $a$ in the Ria de Arosa. Fuhrman et al. (1980) found a similar strong correlation between $\mathrm{TdR}$ and $\mathrm{Chl}$ a but not $\mathrm{TdR}$ and primary production in California coastal waters, suggesting bacterial growth was not coupled to photosynthate release from phytoplankton, but possibly explained by 'sloppy feeding' and incomplete ingestion of phytoplankton by zooplankton.

In the Ria de Arosa, bacterial growth rates and phytoplankton growth rates were in the order of 0.5 and 2 divisions per day (Tables $1 \& 2$ ). An index of specific growth rates for bacteria, TdR incorporation per cell, and phytoplankton carbon production per unit $\mathrm{Chl} a$, can reveal potential interaction in the bacterial and phytoplankton populations, and distribution of rapidly and slowly growing populations in the system (Wright

Table 4. Bacterial abundance, TdR incorporation, specific incorporation rate, production: biomass (P:B), estimated by various investigators for different marine waters. Some of the presented data was back-calculated from conversion factors cited by investigator

\begin{tabular}{|c|c|c|c|c|c|}
\hline Location & $\begin{array}{l}\text { Bacteria } \\
\left(10^{8} 1^{-1}\right)\end{array}$ & $\begin{array}{c}\mathrm{TdR} \\
\left(\mathrm{pmol} \mathrm{l^{-1 }} \mathrm{d}^{-1}\right)\end{array}$ & $\begin{array}{l}\text { Specific incorporation rate } \\
\left(10^{-20} \mathrm{~mol} \text { cell }{ }^{1} \mathrm{~d}^{-1}\right)\end{array}$ & $\begin{array}{l}P: B \\
\left(d^{-1}\right)\end{array}$ & Source \\
\hline New York Bight & $10-14$ & $80-120$ & $3.2-11$ & $1.2-1.5$ & Ducklow \& Kirchman (1983) \\
\hline Danish coast & $8-12$ & $240-6,000$ & $3.4-84$ & $0.68-17$ & Riemann et al. (1984) \\
\hline Celtic Sea & $3-5$ & $5.9-19.4$ & $2.0-4$ & $0.019-0.31$ & Joint/Pomroy (1983) \\
\hline Southern Califomia Bight & $5-20$ & $600-1,800$ & $10-50$ & $0.5-3.3$ & Fuhrman \& Azam (1982) \\
\hline Southem Calıfornia Bight & $1-20$ & $2-500$ & $2-150$ & $0.01-3.0$ & Fuhrman et al. (1980) \\
\hline Chesapeake Bay & $10-80$ & $1000-10,000$ & $20-100$ & $0.2-1.1$ & Ducklow (1982) \\
\hline Georgia Bight & $30-110$ & $240-3,600$ & $7.4-23$ & $0.08-0.42$ & Newell \& Fallon (1982) \\
\hline Ria de Arosa & $2-13$ & $0-190$ & $5.5-31$ & $<0.1-1.28$ & This study \\
\hline
\end{tabular}


1978, Fuhrman et al. 1980, Fuhrman \& Azam 1982, Ducklow \& Kirchman 1983). During this study, we found no significant correlation between specific TdR incorporation rates and bacterial abundance, suggesting bacterial production was bacterial density-independent and the interaction between bacteria was not an important determinant of bacterial growth in the Ria. Studies by Fuhrman et al. (1980) and Fuhrman \& Azam (1982) reported that bacterial production in California coastal waters was bacterial density-independent and more importantly, dependent on phytoplankton standing stocks.

The fastest specific rates of bacterial TdR incorporation in the Ria were found above the $1 \%$ light level but below the depth of maximum photosynthesis. Below the depth of the $1 \%$ light level (and thermocline), specific incorporation rates indicated slowly growing cells. Fuhrman \& Azam (1982) also reported that the fastest rates of bacterial growth were found at depths below the depth of maximum photosynthesis. They suggested that the decomposition of sinking particles and physiological stress of phytoplankton to low nutrients, light and temperature might have released DOC into this region of the water column for bacterial growth. Our data supports the latter for high bacterial growth below the depth of maximum photosynthesis in the Ria de Arosa, although the former cannot be ruled out. For example, during the nutrient-replete period in the Ria an inverse relation between specific TdR incorporation rates and specific rates of photosynthesis for data above the $1 \%$ light level was observed. Whereas, during the later stages of the upwelling episode in the Ria, phytoplankton now deprived of nutrients in the euphotic zone are nutrient stressed, specific rates of photosynthesis decrease, and bacterial specific incorporation rates wind up uniformly high above the thermocline. Although photosynthate release from physiologically stressed phytoplankton is an attractive hypothesis, photosynthate release alone at times may not be sufficient to meet the demands of bacterial growth (Williams \& Yentsch 1976).

\section{Grazing pressure on phytoplankton and bacteria}

Phytoplankton and zooplankton biomass in the Ria exhibited inverse patterns of change before and after the upwelling event (Tables 1 \& 3). This inverse relation has generally been attributed to zooplankton grazing. The estimated zooplankton grazing rates (89 to $124 \% \mathrm{~d}^{-1}$ ) were at times sufficient to crop the measured daily phytoplankton production at the peak of the phytoplankton bloom (March 11). When inorganic nutrients became depleted by $14 \mathrm{March}$, phytoplankton specific rate of photosynthesis (Fig. 5) and zoo- plankton grazing decreased (Table 3). It has been observed in laboratory experiments that zooplankton grazing rate decreases with slower growing phytoplankton (Ryther 1954, Mullin 1963), possibly due to reduced chemical cues or negative feedback (Poulet \& Oulett 1982, Cowles et al. 1986).

Previous studies showed that cultured mussels in the Ria de Arosa are the principal herbivore grazing phytoplankton biomass synthesized during the periodic blooms that develop in response to upwelling (Tenore et al. 1982). Our results show that zooplankton can also be a major sink for upwelling-induced phytoplankton blooms in the Ria, and thus may at times be in direct competition with raft cultures of mussels.

Grazing rates on thymidine-labelled particles (presumably labelled bacteria) were lower than autotrophic particles probably because of the smaller size of the former and an active selection of phytoplankton over detritus and bacteria (Price et al. 1983). In contrast to the observed pattern of grazing on phytoplankton, grazing rates on bacteria (+ detritus) by zooplankton increased during the 'post-bloom' period (Table 3). This phenomenon may be a functional response to more microheterotrophs or 'prey-switching' by zooplankton as a consequence of reduced phytoplankton. The effect of zooplankton grazing on bacterial standing crops is probably negligible. If we calculate the water column clearance rates of free-living bacteria by assuming that all $>0.2 \mu \mathrm{m}$ thymidine-labelled particles are available to zooplankton, we find that less than $10 \%$ of daily bacterial production would be grazed by zooplankton.

\section{CONCLUSIONS}

Our results describe the plankton dynamics during a $7 \mathrm{~d}$ period following an intrusion of upwelled North Atlantic Central Water into the Ria de Arosa. During this period estimates of bacterial production were less than $10 \%$ of phytoplankton production, and zooplankton grazing was sufficient to crop the daily phytoplankton production. These results suggest that zooplankton may at times be in direct competition for food with edible mussels, which are extensively grown on rafts located throughout the inner portion of the Ria de Arosa.

Acknowledgements. The research was supported under 'FOG' (Fisheries and Oceanography off Galicia), a co-operative research program, CCA8309-023, between the University of Maryland and the Institute Español de Oceanografía funded by funds from the Joint Committee for Scientific Technological Cooperation under terms of the Treaty of Friendship and Cooperation between Spain and the University. 


\section{LITERATURE CITED}

Azam, F., Fenchel, T., Field, J. G., Gray, J. S., Meyer-Reil, L. A., Thingstad, F. (1983). The ecological role of watercolumn microbes in the sea. Mar. Ecol. Prog. Ser. 10: $257-263$

Blanton, J. O., Atkinson, L. P., de Castillejo, F., Fernandez, Montero, A. L. (1984). Coastal upwelling off the Ria Bajas Galica, northwest Spain I. Hydrographic studies. J. Cons. int. Explor. Mer. 183: 79-90

Campos-Loriz, M.-J., Gonzalez, N. (1976). Phytoplankton in relation with nutrient concentrations in the Ria de Arosa In: Persoone, G., Jaspers, E. (ed.) 10th European Symposium on Marine Biology, Ostend, Belgium, Vol. 2. Universa Press, Wetteren, p. 111-125

Cowles, T. J., Olson, R. J., Chisholm, S. W. (1986). Food selection by copepods: Discrimination between cells on the basis of food quality. Mar. Biol. (in press)

Ducklow, H. W. (1982). Chesapeake Bay nutrient and plankton dynamics. I. Bacterial biomass and production during spring tidal destratification in the New York River, Virginia, estuary. Limnol. Oceanogr. 27: 651-659

Ducklow, H. W., Kirchman, D. L. (1983). Bacterial dynamics and distribution during a spring diatom bloom in the Hudson River plume, USA. J. Plankton Res. 5: 333-355

Ducklow, H. W., Hill, S. M. (1985). Tritiated thymidine incorporation and the growth of heterotrophic bacteria in warm core rings. Limnol. Oceanogr. 30: 260-272

Durbin, E. G., Krawiec, R. W., Smayda, T. J. (1975). Seasonal studies on the relative importance of different size fractions of phytoplankton in Narragansett Bay (USA). Mar. Biol. 32: 271-287

Frage, F. (1981). Upwelling off the Galician coast, northwest Spain. In: Richards, F. A. (ed.) Coastal upwellings. American Geophysical Union, Washington, D. C., p. 176-182

Fuhrman, J. A., Azam, F. (1982). Thymidine incorporation as a measure of heterotrophic bacterioplankton production in marine surface waters. Evaluation and field results. Mar. Biol. 66: 109-120

Furhman, J. A., Ammerman, J. W., Azam, F. (1980). Bacterioplankton in the coastal eutrophic zone: distributin, activity and possible relationships with phytoplankton. Mar. Biol. 60: 201-207

Harrison, W. G., Platt, T., Calienes, R., Ochoa, N. (1981). Photosynthetic parameters and primary production of phytoplankton populations off the northern coast of Peru. In: Richards, F. A. (ed.) Coastal upwelling. American Geophysical Union, Washington, D. C., p. 303-311

Hobbie, J. E., Daley, R. J., Jasper, S. (1977). A method for counting bacteria on Nuclepore filters. Appl. environ. Microbiol. 33: 1225-1228

Houde, E. D., Lovdal, J. A. (1985). Pattems of variability in ichthyoplankton occurrence and abundance in Biscayne Bay, Florida. Estuar. coast. Shelf Sci. 20: 79-104

Joint, l. R., Pomroy, A. J. (1983). Production of picoplankton and small nanoplankton in the Celtic Sea. Mar Biol. 77 : $19-27$

Larson, U., Hagström, А. (1982). Fractionated phytoplankton primary production, exudate release and bacterial production in a Baltic eutrophication gradient. Mar. Biol. 67: $57-70$

Linley, E. A. S., Newell, R. C., Lucas, M. I. (1983). Quantitative relationships between phytoplankton, bacteria and heterotrophic microflagellates in shelf waters. Mar Ecol. Prog. Ser. 12: 77-89

Malone, T. C., Neale, P. J. (1981). Parameters of light-depen- dent photosynthesis for phytoplankton size fractions in temperate estuarine and coastal environments. Mar Biol. 61. 289-297

Malone, T. C., Falkowski, P. G., Hopkins, T. S., Rowe, G. T., Whitledge, T E. (1983). Mesoscale response of diatom populations to a wind event in the plume of the Hudson River. Deep Sea Res. 30: 149-170

Mullin, M. M. (1963). Some factors affecting the feeding of marine copepods of the genus Calanus. Limnol. Oceanogr 8: $239-250$

Newell, S. Y., Fallon, R. D. (1982). Bacterial productivity in the water column and sediments of the Georgia (USA) coastal zone: estimates via direct counting and parallel measurement of thymidine incorporation. Microb. Ecol. 8: $33-46$

Poulet, S. A., Oulett, G. (1983). The role of amino acids in the chemosensory swarming and feeding of marine copepods. J. Plankton Res. 4: 341-361

Price, H. J., Paffenhöfer, G.-A., Strickler, J. R. (1983). Modes of cell capture in calanoid copepods. Limnol. Oceanogr. 28: $116-123$

Riemann, B., Nielsen, P., Jeppesen, M., Marcussen, B., Fuhrman, J. A. (1984). Diel changes in bacterial biomass and growth rates in coastal environments, determined by means of thymidine incorporation into DNA, frequency of dividing cells (FDC), and microautoradiography. Mar. Ecol. Prog. Ser. 17: 227-235

Roman, M. R., Rublee, P. A. (1981). A method to determine in situ zooplankton grazing rates on natural particle assemblages. Mar. Biol. 65: 303-309

Roman, M. R., Gauzens, A. L., Coules, T. J. (1985). Temporal and spatial changes in epipelagic microzooplankton and mesozooplankton biomass in warm-core Gulf Stream Ring 82-B. Deep Sea Res. 32: 1007-1022

Ryther, J. H. (1954). Inhibitory effects of phytoplankton upon feeding of Paphnia magna with reference to growth reproduction and survival. Ecology $35: 522-533$

Solorzano, L. (1969). Determination of ammonia in natural waters by the phenol hypochlonite method. Limnol Oceanogr 14: 799-801

Strickland, J. D. H., Parsons, T R. (1972). A practical handbook of seawater analysis. Bull. Fish. Res. Bd Can. 167

Tenore, K. R., plus 14 authors. (1982). Coastal upwelling in Rias Bajas, N. W. Spain. Contrasting the benthic regimes of the Ria de Arosa and de Muros. J. mar. Res. 40:701-772

Tenore, K. R., Cal, R. M., Hanson, R. B., Lopez-Jamar, E., Santiago, G., Teitjen, J. H. (1983). Coastal upwelling off the Rias Bajas, Galicia (NW Spain). II. Benthic studies. J. du Conseil 183: 88-97

Van Es, F. B., Meyer-Reil, L. A. (1982). Biomass and metabolic activity of heterotrophic marine bacteria. Adv. microb. Ecol. 6: 111-170

Watson, S. W., Novitsky, T. J., Quimby, H. L., Valois, F. W. (1977). Determination of bacterial number and biomass in the marine environment. Appl. environ. Microbiol. 33: 940-946

Williams, P. J. leB. (1984). Bacterial production in marine food chains: Emperor's new suit of clothes? In: Fasham, M. J. R. (ed.) Flows of energy and materials in marine ecosystems: theory and practice. Plenum, New York, p. 271-299

Williams, P. J. leB., Yentsch, C. S. (1976). An examination of photosynthetic production excretion of photosynthetic products, and heterotrophic utilization of dissolved organic compounds with reference to results from a coastal subtropical sea. Mar. Biol. 35: 31-40 
Wright, R. T. (1978). Measurement and significance of specific activity in the heterotrophic bacteria of natural waters. Appl. environ. Microbiol. 36: 297-305
Yentsch, C. S., Menzel, D. W. (1963). A method for the determination of phytoplankton, chlorophyll and phaeophytin by fluorescence. Deep Sea Res. 10: 221-231

This article was presented by Professor K. R. Tenore; it was accepted for printing on June 19, 1986 